\title{
A millenniumi generáció munkatapasztalatai
}

\section{Millennium Generation Work Experience}

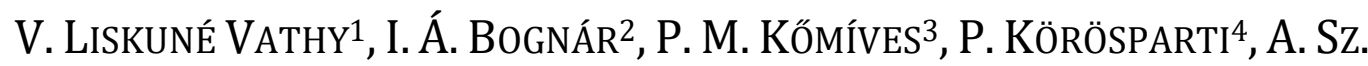 \\ NAGY5
}

${ }^{1}$ Debreceni Egyetem Ihrig Károly Gazdálkodás- és Szervezéstudományok Doktori Iskola, ²Debreceni Egyetem Gazdaságtudományi Kar Gazdálkodástudományi Intézet,

${ }^{3}$ Debreceni Egyetem Gazdaságtudományi Kar, Emberi Erőforrás Menedzsment Tanszék,

${ }^{4}$ Debreceni Egyetem Gazdaságtudományi Kar Gazdálkodástudományi Intézet,

${ }^{5}$ Debreceni Egyetem Gazdaságtudományi Kar Gazdálkodástudományi Intézet,

nagy.adrian@econ.unideb.hu

Absztrakt. Ha nyitott szemmel járunk a mindennapok során, akkor nem kerülheti el figyelmünket a hallgatói munkavégzés jelensége. Ezen tanulmány keretein belül az volt a célunk, hogy megvizsgáljuk a Debreceni Egyetem Gazdaságtudományi Karán első évfolyamon tanulmányaikat megkezdő hallgatók munkatapasztalatainak meglétét, későbbi elhelyezkedési terveit, jövedelmi igényeit. Emellett szakirodalmi vizsgálatok keretében elemezzük a hallgatói munkavégzéssel kapcsolatos legfontosabb forrásokat.

A felsőoktatásba újonnan belépő hallgatók szemléletének változására fontos figyelmet fordítani, mivel tanulmányaik befejezése után aktív munkakeresővé válnak. A Debreceni Egyetem Gazdaságtudományi Karán a 2019/2020-as tanévben mintegy 2000 fó került felvételre, akik közül 1700 meg is kezdte a tanulmányait. A kutatásunkat ezen hallgatók bevonásával végeztük.

Az adatfelvétel a Debreceni Egyetem által szervezett gólyatáborában résztvevő hallgatók körében történt. A felmérés kiterjed többek között a kezdő fizetési igények felmérésére, az eddigi munkatapasztalatokra, a jövőbeni tervekre, ehhez kapcsolódóan a külföldi munkavállalással kapcsolatos hajlandóságra, valamint arra, hogy mely tényezőket veszik figyelembe a munkahely választás során.

Abstract. If we are open-minded in our everyday life, we should not overlook the phenomenon of student work. Within the framework of this study, our aim was to examine the work experience, later employment plans and income needs of students starting their studies at the Faculty of Economics at the University of Debrecen. In addition, we analyze the most important sources related to student work through literature studies.

It is important to pay attention to changing attitudes of newcomers to higher education as they become active job seekers after graduation. At the Faculty of Economics of the University of Debrecen, 
about 1,700 students started their studies in the 2019/2020 academic year. Our research was conducted with the involvement of these students.

The data were collected among students participating in the stork camp organized by the University of Debrecen. The survey covers, among other things, the initial salary requirements, previous work experience, future plans, including the willingness to work abroad, and factors that are taken into account when choosing a job.

\section{Bevezetés}

A 18 év körüli életkorú fiatalok az első munkavállalással kapcsolatos döntésüket már a középiskolában meghozzák, amikor arról döntenek, hogy továbbtanulnak-e valamelyik felsőoktatási intézményben meghirdetett képzésen, vagy inkább munkát vállalnak. Egy debreceni szakközépiskolások körében végzett felmérés eredményei alapján látható, hogy a munkavégzés, ezáltal pedig az önálló jövedelem megszerzésére nyíló reális esély komolyan vonzza az érettségi környékén járó középiskolásokat, jelentős hatást gyakorolva ezzel további életszakaszukra. [1]

A hallgatók tanulmányaik során, a felsőoktatási léthez többféle módon viszonyulhatnak, ami erősen befolyásolja, hogy milyen célok megvalósításáért hajlandóak erőfeszítéseket tenni. A tudásgyarapító orientáció lényege a tudás megszerzése, méghozzá az önmagáért való tudás birtoklása iránti vágy formájában. Az ilyen hallgatókat az elérhető jövedelem, a betölthető munkakör nem motiválja. A moratóriumkereső orientáció célja a hallgatói lét megélése, a munkavállalás elhalasztása. Ebben az esetben a legfőbb motivátor a diákélet utáni vágy lesz. A társadalmi felemelkedést a középpontba helyező orientáció esetén a hallgató elsődleges motivációja a diploma megszerzése, ami az esetek jelentős hányadában valamilyen családi elvárásnak való megfeleléssel magyarázható. Az orientációt követő hallgatók esetében sem tekinthető jelentős motivációnak a jó munkahely megszerzése - további érdekesség, hogy voltaképpen a tudás gyarapodása sem motiválja az ilyen hallgatókat, kizárólag a diploma, az oklevél megszerzése. Az utolsó orientáció bír majd a legnagyobb jelentőséggel a hallgatók munkavégzéshez aló hozzáállása szempontjából. A presztízsszerző orientáció esetén a hallgatók motivációját tanulmányaik során a későbbi jól fizető, magas presztízsű foglalkozási csoportba történő bejutás lehetősége adja majd, vagyis ez az orientáció tekinthető a leginkább alkalmasnak a hosszú távú karrierépítésre. [2] A tanulmányokkal párhuzamosan végzett munka egyik speciális esetköre a duális képzési forma, amikor a hallgató a felsőoktatási intézmény szervezésében szerződött vállalati partnerek által szervezett és biztosított munkát végez pénzbeli ellentételezés fejében. [3] [4] A Magyarországon tanulmányokat folytató külföldi hallgatók motivációjával kapcsolatban több vizsgálat is folyt a közelmúltban. [5] [6]

E tanulmány keretein belül az volt a célunk, hogy szakirodalmi vizsgálatok keretében elemezzük a hallgatói munkavégzéssel kapcsolatos legfontosabb forrásokat. A feltárt eredményeket összevetettük a Debreceni Egyetem Gazdaságtudományi Karán első évfolyamon tanulmányaikat megkezdő hallgatók válaszaival. 


\section{Szakirodalmi áttekintés}

A hallgatók egyetemi tanulmányaikkal párhuzamosan munkát is vállalhatnak, erre pedig több motivációjuk is lehet. A munkavégzés egy különleges típusa az önkéntes munka, amelynek során a hallgatók speciális célok elérése érdekében vállalnak munkavégzést. Ilyen esetekben a hallgatók egy része karitatív munkát végez például oktatási vagy szociális szervezetek keretében, más része azonban elsősorban azért vállal munkát, hogy annak során kapcsolatokat építhessen és olyan tapasztalatokat, szocializációt szerezhessen, amelyet a későbbiekben fizetett bérmunka végzése során is alkalmazhat, amelynek köszönhetően álláskeresőként attraktívabbá válhat a munkaerőpiacon [7] A hallgatói önkéntes munka megjelenési gyakorisága egyelőre nem túl magas, ez elmúlt években végzett kutatások szerint nagyjából a hallgatók több, mint negyede és $40 \%$-a közötti arányban lesz jellemző az ilyen munkavégzés. Emellett ugyanakkor azt is lehet látni, hogy az önkénteskedésre hajlamos hallgatók esetében jellemző lesz az altruista viselkedésmód, amelynek eredményeként a családalapítás során nagyobb hajlandóságot mutatnak az ilyen hallgatók több gyermek vállalására. [8]

A hallgatóként végzett munka célja az esetek jelentős hányadában a tapasztalatszerzés annak érdekében, hogy a későbbiekben az álláskeresés során sikeresebbek legyenek a hallgatók. Ez a hozzáállás tehát komoly tudatosságot feltételez a hallgatókról, amelynek értelmében a későbbi vélt vagy valós sikeresség érdekében hajlandóak rövidebb távon a pénzszerzésről is lemondani és önkéntes munkára áldozni szabad idejüket. Mindez egyébként a felsőoktatási intézmények számára is hasznos lehet, hiszen a munkát vállaló hallgatók közvetlenül, első kézből szereznek munkaerőpiaci tapasztalatokat, amelyek kiváló visszacsatolást jelentenek a képzések eredményességére, a tananyag gyakorlati hasznosíthatóságára vonatkozóan, ez pedig lehetőséget teremt a képzések kurrikulumának frissítésére, optimalizálására is. [9] Mindez pedig maguknak a hallgatóknak is hasznos, hiszen a rendszeres munkavégzéssel a munkavállalóktól elvárt kompetenciákkal rendelkező potenciális munkaerőként tudnak megjelenni a munkaerőpiacon végzésüket követően. [10] A magyarországi felsőoktatási intézmények által fejlesztett és a magyar munkáltatók által elvárt munkavállalói kompetenciák területén különbségek mérhetőek, vagyis vannak olyan kompetenciák, amelyek a munkavállalói sikerességhez elengedhetetlenül fontosak, a felsőoktatási rendszer azonban mégsem alkalmas azok fejlesztésére. Ugyanakkor a munkáltatók nem tartják elegendőnek a munkavállalók önképzés formájában megvalósuló önfejlesztését, vagyis a formális iskolarendszerű felsőoktatási képzésekre továbbra is igény és szükség van nemcsak a munkavállalók, hanem a munkáltatók véleménye szerint is. [11]

A tanulás és a munkavégzés párhuzamos megjelenése pedig nem is feltétlenül veszélyezteti a felsőoktatásban nappali tagozaton jelenleg többségben lévő Z-generáció tagjait, hiszen egyik jellegzetességük, a multitasking, vagyis a párhuzamos feladatvégzés kiválóan megfelel a vázolt élethelyzet által előidézett kihívások sikeres kezelésének. [12] Ennek a feltevésnek azonban ellentmondani látszik a magyar alapképzések esetében 
mért, európai összevetésben is igen magas hallgatói lemorzsolódási ráta. [13] A lemorzsolódó hallgatók egy része azonban önként dönt tanulmányai megszakítása mellett, ebben pedig közrejátszhat a munkavégzés is, hiszen a hallgatók ebben az esetben a munkahelyen elért sikereikre cserélik a felsőoktatást, annak esetleges kudarcait és azzal bíztatva saját magukat, hogy a végzettség hiányában is eredményeket tudnak elérni. [14] Természetesen a Z-generáció tagjait is motiválja a tudás megszerzésének lehetősége, az elérhető anyagi előnyök és a megszerezhető munkatapasztalatok által okozott előnyök. [15]

A Budapesti Műszaki és Gazdaságtudományi Egyetem, a Budapesti Corvinus Egyetem és a Budapesti Gazdasági Egyetem mesterképzésen tanuló hallgatói körében végzett felmérés részletesen foglalkozott azzal a kérdéssel, hogy mi motiválta a hallgatókat a tanulmányaikkal párhuzamosan munka végzésére. A kutatás szerint a hallgatók leginkább azért vállaltak munkát, hogy a megszerzett munkatapasztalatot hasznosítva a későbbiekben könnyebben tudjanak elhelyezkedni. További fontos motiváció volt számukra a szakmai tapasztalatszerzésre vonatkozó lehetőség és a saját autonómia kiépítése is. Az anyagi motivációk, vagyis a létfenntartás-önfenntartás és az anyagi önállóság voltak a legkevésbé fontos motiváló tényezők a munkavállalásra nézve. [16] Ezzel összefüggésben azonban meg kell említeni egy, a Debreceni Egyetem hallgatóinak körében végzett felmérést, amely szerint már eleve a továbbtanulás, és különösen a mesterképzésen történő továbbtanulás legjelentősebb motivációja az anyagi jólét megteremtése, a diplomához kapcsolódó magasabb társadalmi és főleg anyagi megbecsültség megszerzése. [17]

Vannak azonban olyan hallgatók is, akik nem engedhetik meg maguknak azt, hogy ne dolgozzanak az egyetemi éveik alatt, hiszen a jövedelemre a létfenntartás érdekében van szükségük. Mindez részben annak is köszönhető, hogy a felsőoktatás tömegessé vált, így - a társadalmi igazságosság és az esélyegyenlőség teljes társadalmi szinten támogatott elveinek megfelelő módon - alacsonyabb társadalmi státuszú családokból származó fiatalok is lehetőséghez jutottak és bekerülhettek a felsőoktatásba. [18] A munkavállalásban is érdekelt hallgatók a munkára fordított időt több forrásból is biztosíthatják. Annak fedezetét jelentheti a tanulmányokra fordított időkeret, a szabadidő és a tanórán kívüli aktivitások ideje is. A munkavállalás tehát ilyen módon negatívan hathat az egyetemi hallgatók szociális integrációjára. Mindezzel párhuzamosan a munkavégzésnek - természetesen - számos pozitív hatása is lehet a hallgatókra nézve, amelyek közül okvetlenül ki kell emelni az egyetemek által biztosított elméleti oktatást jól kiegészítő gyakorlati tudásgyarapítás, a mindennapok strukturált időbeosztásának képessége, illetve a munkavállaláshoz kapcsolódóan fejlődő soft skillek köre, így például a fejlettebbé váló csoportmunka-képesség és problémamegoldó képesség. [19]

Napjainkban Magyarországon egyáltalán nem reális azt mondani, hogy a felsőoktatásban tanuló hallgatók tanulmányaikkal párhuzamosan folytatott munkavégzése mögött nem áll ott motivációként - és nem ritkán: kényszerként - a jövedelem előteremtésére irányuló szükséglet. A magyar felsőoktatás rendkívül fontos szociális mobilizátor 
feladatot lát el, a képzéseken végző, diplomát szerző hallgatók magasabb társadalmi és jövedelmi státuszba kerülhetnek. A felsőoktatásba történő bekerülés jogszabályi értelemben véve objektív módon történik, azonban tekintettel arra, hogy a középfokú oktatási rendszer csak részben képes felkészíteni a középiskolásokat a felsőfokú tanulmányok megkezdésére, valójában a jobb anyagi körülmények közül érkező középiskolások, akik családja különtanulmányokat is tud finanszírozni, jobb eséllyel kerülnek be az egyetemekre. Ez a hátrány a későbbiekben is megmaradhat, tanulmányi nehézségeket okozhat, illetve a szociális és tanulmányi ösztöndíjrendszerek elavultsága miatt a nehezebb anyagi körülmények közül származó hallgatók gyakran kényszerülnek a felsőfokú tanulmányaikkal párhuzamosan munkavállalásra is. [20] Hasonló jelenséget mértek vidéki magyar felsőoktatási intézményekben is, amelyekben hátrányos helyzetű hallgatók is folytattak tanulmányokat. A felmérés eredményeként a nehéz szociális környezetből származó hallgatók gyakran rosszabb előképzettséggel rendelkeznek jobb gazdasági hátterű társaiknál, mindez pedig a középiskolai tanulmányokkal párhuzamosan látogatott fizetős különórák alacsonyabb megjelenési arányában és az alacsonyabb nyelvvizsga-rátában jelenik meg a leginkább szembeötlő módon. A hátrányos helyzet sajnos a felsőfokú tanulmányok idejére is megmarad, ráadásul, noha a hátrányos helyzetű hallgatók sokkal eltökéltebbek például az egyetemi kontaktórák látogatásában, mint a nem hátrányos helyzetű társaik, a létfenntartáshoz szükséges munkavégzés gyakorta akadályozza őket abban, hogy ténylegesen eljussanak az egyetemi órákra. [21]

Emellett az is egyértelmű, hogy a munkavégzés során különböző vezetői mintákkal találkoznak. Ezek a minták segítenek majd a későbbi karrierjük alatt kialakítani a saját vezetői stílusukat. Itt kell kiemelni, hogy a hallgatók a campusokon belül vagy azokon kívül is vállalhatnak munkát, jellemzően eltérő munkakörben, emellett jelentős hatást gyakorolnak rájuk a különböző mentortanárok és a témavezetők, szakdolgozati konzulens oktatók is. Emellett a hallgatók által megtapasztalt vezetői képet befolyásolja, hogy napjainkban a legnagyobb egyetemek nagyvállalatként múködnek, vagyis menedzsmentjükben számos, az adminisztrációval hivatásszerűen foglalkozó munkavállaló tevékenykedik mindamellett, hogy tudományos kérdésekben természetesen - az akadémiai testületek és vezetők szerepe lesz megkerülhetetlen. [22]

A hallgatók munkavégzésének pozitív externáliái közé tartozik a hallgatói kapcsolatokon alapuló együttműködések kialakítása is, amely lehetőséget teremt oktatási, gazdasági kapcsolatok építésére is. [23]

\section{Anyag és módszer}

A témához kapcsolódó kutatás a Debreceni Egyetem által szervezett gólyatáborban került lebonyolításra 2019 szeptemberében. A primer kutatás keretében kvantitatív adatok elemzését végezük el, melyeket kérdőívezéssel gyűjtöttünk össze. A vizsgálatban a Debreceni Egyetem Gazdaságtudományi Karát megjelölő válaszok kerültek elemzésre. A felmérés során a kérdőívet összesen $\mathrm{N}=507$ fő töltötte ki. A kérdőív tisztítását követően 
502 kérdőív vált értékelhetővé. A kérdőívet kitöltők túlnyomó többsége kora alapján a millenniumi generációhoz tartozik. Az adatok feldolgozása számítógépes programmal, az SPSS for Windows 20.0. matematikai-statisztikai programcsomag használatával történt.

Az elemzések eredményeinek kiértékelése során olyan statisztikai módszertant alkalmaztunk, amely lehetőséget teremt az alapsokaságra való általánosításra is. Mindazonáltal a közölt elemzés eredményei nem tekinthetőek reprezentatívnak, mivel a kérdőíves vizsgálat keretében elért elemszám nem elég magas a kar hallgatói létszámához viszonyítva. Ezért a jelen vizsgálati eredmények és a levont következtetések kizárólag a válaszadók szemszögéből értelmezhetőek. Az elvégzett vizsgálat feltáró jellegű, ebből kifolyólag a jövőben a minta elemszámának növelését követően. amennyiben a reprezentativitás is biztosításra kerül, további kutatás és elemzés elvégzésének is helye lehet.

\section{Következtetések}

A primer kutatás keretében elvégzett adatfelvétel eredményeként megtudhattuk, hogy a Debreceni Egyetem Gazdaságtudományi Karán elvégzett kutatás mintájában szereplő hallgatók elsöprő többsége $(81,67 \%)$ már középiskolás korában, illetve legkésőbb a középiskola befejezését követően, de az egyetemi tanulmányokat megelőzően már szereztek munkatapasztalatot.

Azokban a kérdésekben, amelyekben a hallgatók tanulás utáni terveit vizsgáltuk, igen érdekes eredményekre jutottunk. Egyfelől kifejezetten magas (56,27\%) azon hallgatók aránya, akik a végzést követően szeretnének külföldi munkatapasztalatot szerezni. Ezen a csoporton belül megfigyelhető, hogy a válaszadók főként 2-3 éves munkavállalást terveznek külföldön (55,63\%), viszont 31,33\% szeretne hosszú távon élni és dolgozni is más országokban. Emellett a maradék 13,04\% is szeretne legfeljebb néhány hónapnyi időt Magyarország területén kívül eltölteni.

Ez egyfelől örvendetes, hiszen a külföldön megszerzett munkatapasztalat a Magyarországra való hazatérést követően komoly előnyöket jelent a munkavállalónak és a munkáltatójának egyaránt. Az azonban egyáltalán nem szerencsés a nemzetgazdaság számára, ha a munkavállaló egyáltalán nem tér vissza Magyarországra és tartósan egy külföldi országban telepszik le. A beérkezett válaszokat illetően azt is célszerű figyelembe venni, hogy a válaszadók körében szerepeltek nemzetközi gazdálkodás és gazdaság szakos hallgatók is, akik a szak képzési tervéből és fontosabb jellemzőiből kifolyólag voltaképpen a kezdetektől fogva nemzetközi, de legalábbis multinacionális cégnél végzett karrierre készülnek és törekszenek.

Ennél is érdekesebb a hallgatók kezdő fizetés iránti igényeinek vizsgálata. Az elvégzett elemzés alapján megállapítottuk, hogy a hallgatók esetében a kezdő fizetések iránti igény tekintetében nincsen relevanciája annak, hogy a válaszadó hallgató külföldön vagy belföldön tervez munkát vállalni. Ez azt jelenti, hogy a hallgatók bérigényük megfogalmazása során nincsenek tekintettel a munkavégzés helyére, Magyarországon is 
hasonló béreket várnak el, mint külföldön. Ez egy érdekes fordulat abból a szempontból, hogy Európa - és az Európai Unió - nyugati és keleti államai között hagyományosan jelentős bérkülönbség mérhető a nyugati fizetések javára. Tekintettel arra, hogy számos szektorban már ma is komoly munkaerőhiány alakult ki Magyarországon, a jövő diplomásainak magas bérigénye elgondolkoztató előjelnek is tekinthető.

Szintén érdekes eredményt adott a kezdő fizetések szintjének más változókkal együtt lefolytatott elemzése. Ebből az derült ki, hogy a vizsgált mintában szereplő hallgatók lakóhely szerint komoly eltéréseket mutatnak az elvárt kezdőbérek tekintetében. Míg a kisközségekből érkezők esetében helyenként figyelemfelkeltően alacsony bérigények jelentek meg, a városokból származó vizsgált hallgatók bérigénye jellemzően magas - és nemcsak vidéki társaikhoz, hanem a reálisan elérhető bér szintjéhez mérten is.

\section{Irodalomjegyzék}

[1.] Kőmíves P. M. - Erdős A. - Körösparti P. (2018): Debreceni szakközépiskolai tanulók pályaválasztásának aktuális kérdései. International Journal of Engineering and Management Sciences, Vol. 3, No. 4. pp. 308-319.

[2.] Pusztai G. (2013): A felsőoktatás munkára felkészítő szerepe a hallgatók értelmezésében. In: Kun A. I. - Polónyi I. (szerk.): Az Észak-Alföldi régió helyzete: Képzés és munkaerőpiac. Új Mandátum Kiadó, Budapest. pp. 9-29.

[3.] Mikáczó A. - Varga E. (2015): Minőségi felsőoktatás vs. minőségi diploma, avagy a humántőkébe való képzési befektetés hasznosulása munkaerőpiaci aspektusból. Studia Mundi - Economica, Vol. 2, No. 3. pp. 44-53.

[4.] Fenyves, V. (2019): A gazdaságtudományi területen duális képzésben tanuló hallgatói létszám alakulása Magyarországon CONTROLLER INFO VII: 3 pp. 34-38., $5 \mathrm{p}$.

[5.] Böcskei, E. Bács, Z. Kovács, B. Tarnóczi, T. Fenyves, V. (2019):A nemzetközi diplomamobilitás stratégiai irányvonalai - a Magyarországon tanulmányokat folytató külföldi hallgatók motiváció, valamint a külföldi tanulmányokat befolyásoló tényezők vizsgálata COMPETITIO XVIII : 1-2 pp. 3-38. , 36 p.

[6.] Fenyves, V, Bács, Z. Kovács, B., Tarnóczi, T., Nemeslaki, A. Böcskei, E. (2019): ANALYSIS OF FACTORS INFLUENCING FOREIGN STUDIES-STRATEGIC DECISIONS-RESULTS OF A HUNGARIAN SURVEY JOURNAL OF ENTREPRENEURSHIP EDUCATION 22 : 5 pp. 1-21. Paper: 1528-2651-22-5-452, $21 \mathrm{p}$.

[7.] Fényes H. - Lipcsei L. - Szeder D. V. (2012): Önkéntesség a Debreceni Egyetem hallgatói táborában. In: Dusa Á. R. - Kovács K. - Márkus Zs. - Nyüsti Sz. - Sőrés A. (szerk.): Egyetemi élethelyzetek. Ifjúságszociológiai tanulmányok II. Debreceni Egyetemi Kiadó, Debrecen. pp. 99-120. 
[8.] Fényes H. - Markos V. (2018): A felsőoktatási hallgatók önkéntessége és a hallgatók családterveinek összefüggése. Demográfia, Vol. 61, No. 4. pp. 293-320.

[9.] Markos V. (2014): Egyetemisták a munka világában. In: Fényes H. - Szabó I. (szerk.): Campus-lét a Debreceni Egyetemen. Ifjúságszociológiai tanulmányok. Debreceni Egyetemi Kiadó, Debrecen. pp. 109-132.

[10.] Szőcs A. (2014): Teher alatt nő a pálma: A hallgatók munkához való viszonya a Debreceni Egyetemen. In: Fényes H. - Szabó I. (szerk.): Campus-lét a Debreceni Egyetemen. Ifjúságszociológiai tanulmányok. Debreceni Egyetemi Kiadó, Debrecen. pp. 159-182.

[11.] Varga E. - Szira Z. - Boda H. - Hajós L. (2017): A munkaerőpiacon elvárt kompetenciák relevanciájának összehasonlító elemzése a munkáltatók és a felsőoktatásban végzős fiatal munkavállalók aspektusából. Studia Mundi Economica, Vol. 4, No. 1. pp. 82-93.

[12.] Nagy S. (2019): Az emberi erőforrás menedzsment aktuális kihívásai - elméleti és gyakorlati vonatkozások élelmiszermérnök hallgatók számára. Szegedi Tudományegyetem, Mérnöki Kar, Szeged. p. 89.

[13.] Derényi A. (2015): Bizonyítékokra alapozott kormányzás és a kommunikáció képzés. Jelkép. DOI: 10.20520 pp. 1-21.

[14.] Miskolczi P. - Bársony F. - Király G. (2018): Hallgatói lemorzsolódás a felsőoktatásban: elméleti, magyarázati utak és kutatási eredmények összefoglalása. Iskolakultúra, Vol. 28, No. 3-4. pp. 87-105.

[15.] Juhász Cs. (2017): Z generációs hallgatók felsőoktatási motivációjának vizsgálata. Közép-Európai Közlemények, Vol. 10, No. 2. pp. 131-141.

[16.] Takács S. - Németh M. - Juhászné Klér A. - Toarniczky A- (2017): Az egyetem melletti munkavégzés segítő és gátló tényezői diákszemmel - kérdőíves felmérés a BCE, BGE és BME mesterszakos hallgatói körében. Vezetéstudomány, Vol. 48, No. 3. pp. 39-55.

[17.] Gergely É. - Nagy R. (2015): Gazdasági szakos hallgatók tanulási motivációjának és személyes kompetenciáinak vizsgálata. Közép-Európai Közlemények, Vol. 8, No. 4. pp. 197-205.

[18.] Kárászi Zs. - Kocsis Zs. (2017): Debreceni és nagyváradi egyetemisták munkavállalási szokásainak összehasonlítása. In: Tóth P. - Hanczvikkel A. Duchon J. (szerk.): Tanulóközpontú oktatás, módszertani megújulás a szakképzésben és a felsőoktatásban. VII. Trefort Ágoston Tanárképzési Konferencia Tanulmánykötet. Óbudai Egyetem Trefort Ágoston Mérnökpedagógiai Központ, Budapest. pp. 169-186. 
[19.] Óvári V. - Oroszné Perger M. (2019): A munka, a magánélet és a tanulmányok közti egyensúly vizsgálata a felsőoktatásban tanuló diákok körében. Opus et Educatio, Vol. 6, No. 1. pp. 43-53.

[20.] Török I. (2018): Gondolatok a felsőoktatás (saját) feladatairól. Köz-Gazdaság Review of Economic Theory and Policy, Vol. 13, No. 4. pp. 199-213.

[21.] Berei E. B. (2018): Krónikus betegség a felsőoktatásban? Lemorzsolódáskockázat hátrányos helyzetű hallgatók körében. In: Pusztai G. - Szigeti F. (szerk.): Lemorzsolódás és perzisztencia a felsőoktatásban. Debreceni Egyetemi Kiadó, Debrecen. pp. 284-298.

[22.] Lewis, Jonathan S. (2019): An empirical study of the role of student employment in leadership learning. New Directions for Student Leadership, Vol. 2019, No. 162. pp. 37-47.

[23.] Nábrádi A, - Dékán T, - Bittner B, - Bács Z. (2011): Egyetemi külső gazdasági kapcsolatok fejlesztésének lehetőségei Paper 33 In: IX. Regionális Tanácsadási Konferencia „Gazdálkodás a lehetőségekkel - az önkéntesség jegyében 